\title{
ANALISIS TINGKAT KEPUASAN PENGGUNA APLIKASI GRAB KOTA LUBUKLINGGAU MENGGUNAKAN FRAMEWORK PIECES
}

\author{
Cindi Wulandari, Elmayati, Yulia Citra \\ 1,2,3 Program Studi Sistem Informasi, Univarsitas Bina Insan, Lubuklinggau

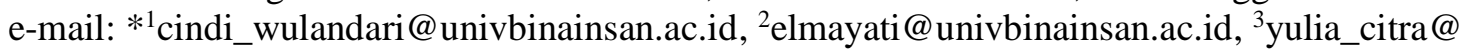 \\ univbinainsan.ac.id
}

\begin{abstract}
Abstrak
Masalah pada penelitian ini adalah bagaimana tingkat kepuasan pengguna aplikasi Grab Kota Lubuklinggau menurut persepsi konsumen dengan diukur menggunakan framework PIECES (performance, information, economic, control, efficiency, dan service). Penelitian ini menggunakan metode pengumpulan data, dengan cara melakukkan pengamatan dan pencacatan langsung pada tempat penelitian, melakukan tanya jawab langsung pada nara sumber dan penyebaran kuisioner kepada pengguna layanan Grab. Populasi dalam penelitian adalah pengguna aplikasi Grab Lubuklinggau dimana jumlah sampel yang diambil sebanyak 91 responden dengan menggunakan rumus slovin. Tujuan dari penelitian ini adalah untuk mengetahui tingkat kepuasan pengguna teknologi informasi pada Aplikasi Grab Kota Lubuklinggau yang diukur dengan menggunakan framework PIECES. Hasil penelitian menunjukkan bahwa dari keseluruhan uji validitas dan reliabilitas setiap item pernyataan kuesioner valid dan reliabel. Adapun uji regresi linier berganda menunjukkan bahwa 6 (enam) variabel memiliki pengaruh signifikan terhadap kepuasan pengguna (konsumen) Grab Lubuklinggau kecuali pada variabel economic.
\end{abstract}

Kata Kunci : Kepuasan pengguna; Teknologi Informasi; PIECES

\begin{abstract}
The problem in this study was how consument satisfy level on Grab Application in Lubuklinggau based on consument perception measured by framework PIECES (Performance, Information, Economic, Control, Efficiency, and Service). This study used collecting data method, by observation and record the research place, interview to interviewees and distribute the questionaires to the Grab service consument. The population in this study was all the Grab Application consument, it was 91 consument as the sample callculated by Slovin formula. The goal of this study was to know consument satisfy level on Information Technology Grab Application in Lubuklinggau, which measures by PIECES framework. The study result show that from validitas and reliability test all of the questionaires item were valid and reliable for multiple linier regretion test show that 6 (variable) have significant effect on consument satisty level except in economic variable.
\end{abstract}

Keywords: Consument satisfy; Information Technology; PIECES 


\section{PENDAHULUAN}

Penggunaan teknologi informasi (TI) tidak melihat dari besar kecilnya suatu organisasi [1]. TI telah merambah ke smartphone, salah satu yang berdasarkan pada handset Android.

Aplikasi Grab dapat dijadikan sebagai wadah komunikasi antara driver dan konsumen selain itu, hadirnya Grab menjawab kebutuhan konsumen bahwa segala sesuatu dapat dilakukan dengan praktis. Aplikasi Grab Kota Lubuklinggau belum pernah dilakukan analisis tingkat kepuasan pengguna, serta belum adanya pengukuran variabel terhadap kepuasan pengguna layanan teknologi informasi pada aplikasi Grab kota Lubuklinggau, sehingga belum diketahui secara pasti apakah aplikasi tersebut memenuhi kepuasan pengguna atau tidak.

Keberadaan teknologi informasi berupa aplikasi Grab yang berkualitas akan berpengaruh terhadap kepuasan pengguna. Peneliti menyadari bahwa Grab dikota Lubuklinggau perlu diadakan pengukuran tingkat kepuasan pengguna pada aplikasi Grab konsumen. Kualitas aplikasi Grab konsumen akan dianalisis dengan menggunakan framework PIECES dari segi Performance (Kehandalan), Information (Informasi), Economic (Ekonomi), Control (pengendalian dan pengamanan), Efeciency (Efisiensi), dan Service (Pelayanan).

Dalam hal ini, fokus penelitian yang dijadikan acuan adalah terkait dengan masalah tingkat kepuasan. Oleh karena itu, peneliti melakukan langkah kajian terhadap beberapa hasil penelitian yakni Pertama, penelitian yang dilakukan oleh Adi Supriyatna, pada tahun 2015, dengan judul "Analisis Dan Evaluasi Kepuasan Pengguna Sistem Informasi Perpustakaan Dengan Menggunakan Pieces Framework"[2]. Kedua, penelitian yang dilakukan oleh Muhamad Sigid Safarudin, pada tahun 2018, dengan judul "Analisis Kepuasan
Pengguna Marketplace Tokopedia Dengan metode PIECES di Tokopedia Community Batam"[3]. Ketiga, penelitian yang dilakukan oleh Yodi, pada tahun 2017, dengan judul "Analisis Sistem Informasi Akademik Mahasiswa Pada Stmik Gici Batam Menggunakan Metode Pieces"[4].

\section{TINJAUAN PUSTAKA}

\subsection{Analisis}

Analisis adalah penelitian yang sejak awal terjun kelapangan berinteraksi dengan latar dan orang (subjek) dalam rangka pengumpulan data [5].

Kepuasan pengguna dapat diartikan sebagai sesuatu keadaan dalam diri seseorang atau sekelompok orang yang telah berhasil mendapatkan sesuatu yang dibutuhkan dan diinginkannya[6].

\subsection{Kepuasan Pengguna}

Kepuasan (satisfaction) berasal dari bahasa latin yang artinya cukup baik, memadai dan facio artinya melakukan atau membuat. Kepuasan bisa diartikan sebagai upaya pemenuhan sesuatu atau membuat sesuatu memadai [7]. Kepuasan pengguna dapat diartikan sebagai sesuatu keadaan dalam diri seseorang atau sekelompok orang yang telah berhasil mendapatkan sesuatu yang dibutuhkan dan diinginkannya [3].

\subsection{Teknologi Informasi dan Layanan Teknologi Informasi \\ Teknologi Informasi merupakan} kombinasi teknologi komputer (perangkat keras dan perangkat lunak) untuk mengolah dan menyimpan informasi dengan teknologi komunikasi, untuk melakukan transmisi informasi [8]. Teknologi Informasi adalah meliputi segala hal yang berkaitan dengan proses, penggunaan sebagai alat bantu, manipulasi, dan pengelolaan informasi [9]. IT Service (layanan teknologi informasi) 
ialah kemampuan perusahaan dalam memberikan suatu nilai jual kepada para pelanggan/ pengguna dalam bentuk layanan, yang didasarkan dan dipengaruhi oleh setiap kebutuhan-kebutuhan yang diperlukan oleh pelanggan [10]. Secara umum, berbagai persyaratan untuk perangkat lunak yang berkualitas tinggi harus disetujui oleh orang-orang yang terlibat dalam pengembangan dan dukungan sistem perangkat lunak melalui berbagai kegiatan penjaminan mutu, sedangkan untuk klaim kualitas yang sangat baik membutuhkan dukungan dari bukti yang didasarkan pada analisis dan pengukuran yang konkret [11].

\subsection{Aplikasi Grab}

Aplikasi Grab tersedia untuk sistem operasi Android, iOS, dan BlackBerry. Grab jika diterjemahkan kedalam bahasa Indonesia artinya mengambil/ menangkap/ merebut. Grab (sebelumnya dikenal sebagai GrabTaxi) adalah sebuah perusahaan yang melayani aplikasi penyedia transportasi. Perusahaan Grab didirikan oleh Anthony Tan sebagai CEO sekaligus Founder dari Grab. Grab berdiri pada tahun 2012 dan terus berkembang hingga sekarang. Saat ini Grab berkembang dikawasan Asia tenggara, termasuk Indonesia [12].

\subsection{PIECES}

PIECES merupakan suatu kerangka kerja yang digunakan untuk klasifikasi permasalahan yang ada berdasarkan kriteria: Performance, information, economic, control, Efficiency dan service [4]. PIECES framework adalah sebuah metode yang digunakan untuk mengklasifikasikan suatu problem, opportunities, dan directives yang terdapat pada bagian scope definition, analisis dan perancangan sistem [13]. Framework ini dikenal dengan Analisis Pieces (Performance, Information, Economic,
Control, Efficiency, Service) [14]. Motode PIECES adalah suatu model evaluasi sistem informasi yang berupa kerangka yang dipakai untuk mengklasifikasikan suatu masalah. Dalam PIECES terdapat enam buah variabel yang digunakan untuk menganalisa sistem informasi yakni [2]:

a. Performance (Kehandalan) analisis ini dilakukan untuk mengetahui kinerja sebuah sistem, apakah berjalan dengan baik atau tidak.

b. Information (Informasi dan data) analisis ini digunakan untuk mengetahui seberapa banyak dan seberapa jelas informasi yang akan dihasilkan untuk satu pencarian.

c. Economics (Nilai Ekonomis) analisis ini dilakukan untuk mengetahui apakah suatu sistem itu tepat diterapkan dilihat dari segi financial dan biaya yang dikeluarkan.

d. Control and Security (Pengamanan dan pengendalian) analisa ini digunakan untuk mengetahui sejauh mana pengawasan dan kontrol yang dilakukan agar sistem tersebut berjalan dengan baik.

e. Efficiency (Efisiensi) Analisa ini dilakukan untuk mengetahui apakah suatu sistem itu efisien atau tidak, dengan input yang sedikit bisa menghasilkan sebuah output yang memuaskan.

f. Service (Pelayanan) Analisis ini digunakan untuk mengetahui bagaimana pelayanan yang dilakukan dan mengetahui permasalahan-permasalahan yang ada terkait tentang pelayananan

\subsection{Populasi}

Populasi adalah wilayah generalisasi yang terdiri atas: objek/subyek yang mempunyai kualitas dan karakteristik tertentu yang di tetapkan oleh peneliti untuk mempelajari dan kemudian ditarik kesimpulannya [15]. Jadi populasi bukan 
hanya orang, tetapi juga obyek dan benda benda alam yang lain. Populasi juga bukan sekedar jumlah yang ada pada objek/subyek yang dipelajari, tetapi meliputi seluruh karakteristik/sifat yang dimiliki oleh subyek atau obyek itu. Populasi adalah keseluruhan objek penelitian yang dapat terdiri dari manusia, benda-benda, hewan-hewan, tumbuh-tumbuhan, gejala-gejala, nilai tes atau peristiwa-peristiwa sebagai sumber data yang memiliki karakteristik tertentu dalam suatu penelitian [16].

\subsection{Sampel}

Sampel adalah bagian dari jumlah dan karakteristik, yang dimiliki oleh populasi tersebut. Bila populasi besar, dan peneliti tidak mungkin mempelajari semua yang ada pada populasi, misalnya karena keterbatasan dana, tenaga dan waktu, maka peneliti dapat menggunakan sampel yang diambil dari populasi itu. Apa yang dipelajari dari sampel itu, kesimpulannya akan dapat diberlakukan untuk populasi. Untuk itu sampel yang diambil dari populasi harus betul-betul representatif (mewakili) [15]. Sampel adalah sebagian saja dari seluruh jumlah populasi, yang diambil dari populasi dengan cara sedemikian rupa sehingga dapat dianggap mewakili seluruh anggota populasi [16].

\subsection{Skala Likert}

Skala Likert digunakan untuk mengukur sikap, pendapat, dan persepsi seseorang atau kelompok orang tentang fenomena sosial dalam penelitian. Dengan skala Likert maka variabel akan di ukur dijabarkan menjadi indikator variabel kemudian indikator tersebut dijadikan sebgai titik tolak untuk menyusun item-item yang dapat berupa pernyataan atau pertanyaan [15].

\subsection{SPSS}

Statistical Product and Service Solution atau biasa dikenal dengan SPSS merupakan program pengolah data statistik mulai dari model aplikasi statistik deskriptif (mean, median, modus, kuartil, persentil, range, distribusi, varians, standar deviasi, standar eror, nilai kemiringan, dan lain-lain [16]. SPSS merupakan salah satu software analisis statistik yang cukup lengkap digunakan oleh penggunanya, mulai dari analisis univariate, bivariate sampai multivariate baik uji untuk membedakan maupun hubungan. Tampilan univarite mulai dalam bentuk tabel sampai dengan grafik juga sudah tersedia. SPSS mempunyai empat menu, hal ini yang dimaksudkan untuk memberikan space yang berbeda dengan proses mengejarkan analisis data dan mengamati hasil analisis [17].

\section{METODOLOGI PENELITIAN}

Penelitian ini menggunakan pendekatan kuantitatif yang bersifat deskriptif, penelitian yang dilakukan dengan cara pengolahan dan penyajian data dengan mempergunakan perhitungan statistika yang melibatkan angka-angka atau skor/nilai sehingga memungkinkan peneliti untuk mengambil keputusan secara obyektif. Data dikumpulkan melalui penyebaran kuesioner yang akan di uji validitas, uji reabilitas dan uji regresi linier sederhana dan berganda.

\subsection{Teknik Pengambilan Sampel}

Dalam penelitian ini sampel yang diambil berdasarkan area yang ada dalam populasi, diharapkan hasil yang diperoleh akan dapat menggambarkan sifat dari populasi yang bersangkutan, responden yang akan menjadi subjek penelitian yaitu konsumen Grab Lubuklinggau yang 
memiliki kriteria seperti ditunjukan tabel 1 berikut.

Tabel 1. Kriteria sampel

\begin{tabular}{|c|c|}
\hline Sampel & Kriteria \\
\hline \multirow{3}{*}{$\begin{array}{l}\text { Pengguna } \\
\text { Aplikasi Grab } \\
\text { Kota } \\
\text { Lubuklinggau }\end{array}$} & $\begin{array}{l}\text { Menggunakan } \\
\text { aplikasi Grab } \\
\text { minimal 2 kali }\end{array}$ \\
\hline & $\begin{array}{l}\text { Mengerti dan } \\
\text { memahami dalam } \\
\text { penggunaan aplikasi } \\
\text { Grab }\end{array}$ \\
\hline & $\begin{array}{l}\text { Berdomisili di kota } \\
\text { Lubuklinggau }\end{array}$ \\
\hline
\end{tabular}

Dalam teknik pengambilan sampel ini, peneliti menggunakan teknik sampling insidental. Sampling insidental adalah teknik penentuan sampel berdasarkan kebetulan, yaitu siapa saja yang secara kebetulan insindental bertemu dengan peneliti dapat digunakan sebagai sampel bila dipandang orang yang kebetulan ditemui itu cocok sebagai sumber data [15]. Dalam menentukan jumlah sampel peneliti menggunakan rumus slovin [3].

$$
\mathrm{n}=\frac{N}{1+N(e)^{2}}
$$

Keterangan :

$\mathrm{n}=$ Jumlah sampel

$\mathrm{N}=$ Jumlah populasi

$\mathrm{e}=$ Tingkat kesalahan $(10 \%)$.

Berdasarkan data yang telah peneliti peroleh total populasi dari seluruh pengguna Grab Konsumen Lubuklinggau yaitu berjumlah 1020 orang. Dari segi toleransi kesalahan sebesar $10 \%$, maka jumlah sampel yang diperoleh dari total populasi yaitu:

$$
\begin{aligned}
& \mathrm{n}=\frac{N}{1+N(e)^{2}} \\
& \mathrm{n}=\frac{1020}{1+1020(0,1)^{2}} \\
& \mathrm{n}=\frac{1020}{1+1020(0,01)} \\
& \mathrm{n}=\frac{1020}{1+10,2}
\end{aligned}
$$

$$
\begin{aligned}
& \mathrm{n}=\frac{1020}{11,2} \\
& \mathrm{n}=91,07
\end{aligned}
$$

\subsection{Analisis Kebutuhan dan Desain Analisis \\ Kuesioner diukur berdasarkan skala} likert dan dirancang secara khusus untuk mengukur enam indikator terhadap kepuasan pengguna teknologi informasi pada aplikasi Grab, yakni: Performance (kinerja), Information (informasi), Economic (ekonomi), Control

\begin{tabular}{|c|c|c|}
\hline $\mathbf{N}$ & Variabel & Indikator \\
\hline \multirow[t]{4}{*}{1} & \multirow[t]{4}{*}{$\begin{array}{l}\text { Performance } \\
\text { (kinerja) } \\
\text { (X1) }\end{array}$} & $\begin{array}{l}\text { Aplikasi Grab memiliki } \\
\text { kualitas loading yang } \\
\text { cepat saat di akses }\end{array}$ \\
\hline & & $\begin{array}{l}\text { Interface interaksi antar } \\
\text { mudah di pahami }\end{array}$ \\
\hline & & $\begin{array}{l}\text { Memiliki proses input } \\
\text { yang mudah }\end{array}$ \\
\hline & & $\begin{array}{l}\begin{array}{l}\text { Memiliki Fitur yang } \\
\text { lengkap }\end{array} \\
\end{array}$ \\
\hline \multirow[t]{4}{*}{2} & \multirow[t]{4}{*}{$\begin{array}{l}\text { Information } \\
\text { (informasi) } \\
\text { (X2) }\end{array}$} & $\begin{array}{ll}\text { Menyediakan informasi } \\
\text { sesuai } \\
\text { pengguna }\end{array}$ \\
\hline & & $\begin{array}{l}\text { Menyediakan informasi } \\
\text { yang tepat dan akurat }\end{array}$ \\
\hline & & $\begin{array}{l}\text { Tidak membutuhkan } \\
\text { waktu yang lama untuk } \\
\text { menyediakan informasi }\end{array}$ \\
\hline & & $\begin{array}{l}\text { Menyediakan Informasi } \\
\text { yang up to date }\end{array}$ \\
\hline \multirow[t]{4}{*}{3} & \multirow{4}{*}{$\begin{array}{l}\text { Economic } \\
\text { (ekonomi) } \\
\text { (X3) }\end{array}$} & $\begin{array}{l}\text { Menawarkan biaya } \\
\text { layanan jasa yang sesuai }\end{array}$ \\
\hline & & $\begin{array}{l}\text { Menawarkan harga yang } \\
\text { transparan }\end{array}$ \\
\hline & & $\begin{array}{l}\text { Menawarkan biaya yang } \\
\text { konsisten }\end{array}$ \\
\hline & & Menjamin keamanan \\
\hline
\end{tabular}
(pengendalian dan keamanan), Efficiency (efisiensi), Service (layanan).

\subsection{Instrumen Penelitian}

Instrumen penelitian dapat dilihat melalui Tabel 2 dibawah ini.

Tabel 2. Daftar Pernyataan Kuisioner 


\begin{tabular}{|c|c|c|}
\hline & & data pengguna \\
\hline \multirow[t]{4}{*}{4} & \multirow{4}{*}{$\begin{array}{c}\text { Control } \\
\text { (pengendalian } \\
\text { dan keamanan) } \\
\text { (X4) }\end{array}$} & $\begin{array}{l}\text { Memiliki batasan- } \\
\text { batasan akses pengguna }\end{array}$ \\
\hline & & $\begin{array}{l}\text { Aman dari serangan } \\
\text { virus }\end{array}$ \\
\hline & & $\begin{array}{l}\text { Memilki fitur keamanan } \\
\text { yang khusus (seperti } \\
\text { tombol darurat yang ada } \\
\text { pada aplikasi) }\end{array}$ \\
\hline & & $\begin{array}{l}\text { Berhenti berfungsi, } \\
\text { crash atau error }\end{array}$ \\
\hline 5 & \multirow{4}{*}{$\begin{array}{l}\text { Efficiency } \\
\text { (efisiensi) } \\
\text { (X5) }\end{array}$} & $\begin{array}{ll}\text { Mudah } & \text { untuk } \\
\text { dioperasikan }\end{array}$ \\
\hline & & $\begin{array}{l}\text { Hemat waktu, biaya dan } \\
\text { tenaga }\end{array}$ \\
\hline & & $\begin{array}{l}\text { Tidak memerlukan } \\
\text { sumber daya manusia } \\
\text { yang banyak untuk } \\
\text { menjalankan aplikasi }\end{array}$ \\
\hline & & \begin{tabular}{lr}
\multicolumn{2}{l}{ Menawarkan layanan } \\
pusat bantuan yang \\
akurat
\end{tabular} \\
\hline \multirow[t]{10}{*}{6} & \multirow[t]{10}{*}{$\begin{array}{c}\text { Service } \\
\text { (Pelayanan) } \\
\text { (X6) }\end{array}$} & $\begin{array}{lr}\text { Menawarkan layanan } \\
\text { pusat bantuan yang } \\
\text { akurat }\end{array}$ \\
\hline & & $\begin{array}{lr}\text { Menyedikan } & \text { fitur } \\
\text { bagikan } & \text { lokasi } \\
\text { perjalanan } & \text { kepada } \\
\text { orang-orang terdekat }\end{array}$ \\
\hline & & $\begin{array}{l}\text { Menyedikan fitur pesan } \\
\text { foto atau suara di Grab } \\
\text { Chat agar titik temu } \\
\text { lebih akurat }\end{array}$ \\
\hline & & $\begin{array}{lr}\text { Menyedikan } & \text { fitur } \\
\text { tombol darurat } & \text { (SOS) } \\
\text { yang efektif } & \\
\end{array}$ \\
\hline & & $\begin{array}{l}\text { Menyedikan fitur lokasi } \\
\text { penjemputan detail } \\
\text { (POI) }\end{array}$ \\
\hline & & $\begin{array}{l}\text { Menyediakan fitur } \\
\text { mengubah tujuan dalam } \\
\text { perjalanan }\end{array}$ \\
\hline & & $\begin{array}{ll}\text { Menyediakan fitur } \\
\text { membatalkan } \\
\text { pemesanan efektif }\end{array}$ \\
\hline & & $\begin{array}{l}\text { Menyediakan layanan } \\
\text { rewards }\end{array}$ \\
\hline & & $\begin{array}{l}\text { Menyediakan layanan } \\
\text { kartu kamu yaitu untuk } \\
\text { metode pembayaran }\end{array}$ \\
\hline & & Menyediakan layanan \\
\hline
\end{tabular}

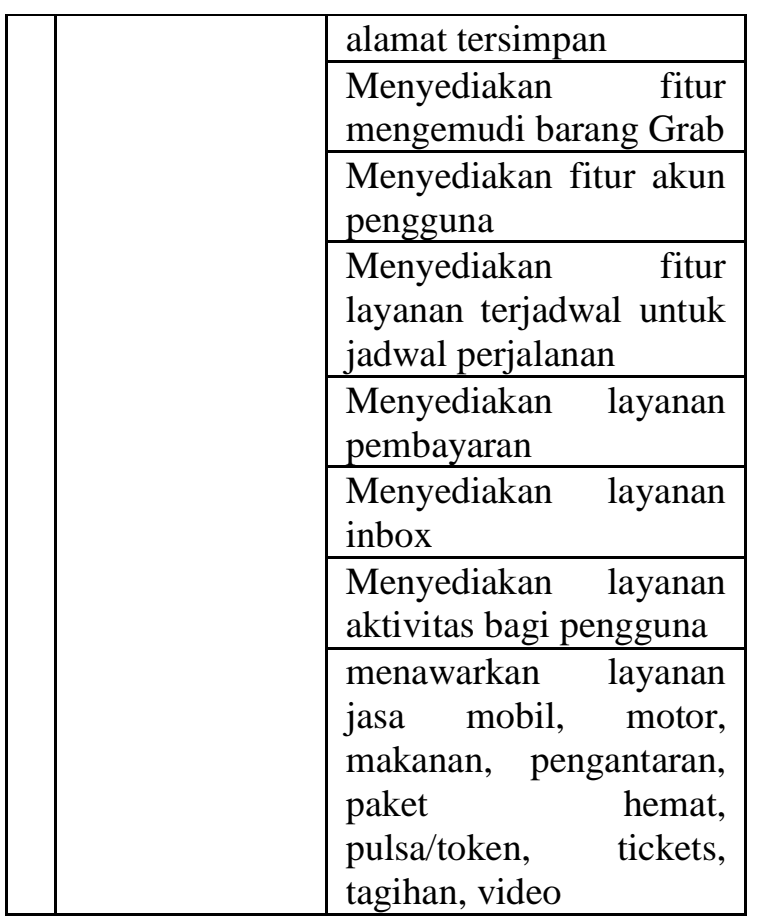

\section{HASIL DAN PEMBAHASAN}

Peneliti mendapatkan hasil penelitian berupa nilai perhitungan serta pembahasannya sebagai berikut :

\subsection{Uji Validitas}

Pengujian butir pernyataan dengan nilai koefisien korelasi $\mathrm{r}$ hitung $>\mathrm{r}$ tabel maka butir pernyataan tersebut dinyatakan valid. Cara menentukan nilai $r$ tabel dengan taraf signifiakn 5\% untuk derajat kebebasan $(\mathrm{dk}=\mathrm{n}-2)$ atau $(\mathrm{dk}=91-2=89)$, karena nilai $\mathrm{r}$ tabel dengan $\mathrm{N} 89$ tidak ada maka peneliti mengambil nilai $\mathrm{N}$ yang paling terdekat yaitu $\mathrm{N}=90$, sehingga $\mathrm{r}$ tabel yang digunakan sebesar 0,207. Berikut menampilkan hasil uji validitas untuk setiap variabel yang ditunjukkan dari tabel dibawah ini. 
Tabel 3. Hasil Uji Validitas Variabel Performance (kinerja) / X1

\begin{tabular}{|l|l|c|c|c|}
\hline No & \multicolumn{1}{|c|}{ Pernyataan } & $\begin{array}{c}\text { Total } \\
\text { Correlation } \\
\mathrm{R}_{\text {hitung }}\end{array}$ & $\begin{array}{c}\mathrm{R}_{\text {tabel }} \\
\mathrm{N}=91-2)\end{array}$ & Ket \\
\hline 1 & $\begin{array}{l}\text { Aplikasi Grab memiliki } \\
\text { kualitas loading yang cepat } \\
\text { saat di akses }\end{array}$ & 0,747 & 0,207 & Valid \\
\hline 2 & $\begin{array}{l}\text { Interface (antarmuka/ interaksi } \\
\text { antar pengguna seperti ikon, } \\
\text { pergerakan gestur, bahasa dll } \\
\text { yangada pada aplikasi) mudah } \\
\text { di pahami }\end{array}$ & 0,709 & 0,207 & Valid \\
\hline 3 & $\begin{array}{l}\text { Aplikasi Grab memiliki proses } \\
\text { input yang mudah }\end{array}$ & 0,620 & 0,207 & Valid \\
\hline 4 & $\begin{array}{l}\text { Aplikasi Grab memiliki Fitur } \\
\text { yang lengkap sesuai dengan } \\
\text { kebutuhan pengguna }\end{array}$ & 0,661 & 0,207 & Valid \\
\hline
\end{tabular}

Tabel 4. Hasil Uji Validitas Variable Information (informasi) / (X2)

\begin{tabular}{|c|c|c|c|c|}
\hline No & Pernyataan & $\begin{array}{c}\text { Total } \\
\text { Correlation } \\
\mathrm{R}_{\text {hitung }}\end{array}$ & $\begin{array}{c}\mathrm{R}_{\text {tabel }} \\
\mathrm{N}=91-2\end{array}$ & Ket \\
\hline 1. & $\begin{array}{l}\text { Aplikasi Grab menyediakan } \\
\text { informasi sesuai kebutuhan } \\
\text { pengguna }\end{array}$ & 0,553 & 0,207 & Valid \\
\hline 2 & $\begin{array}{l}\text { Aplikasi Grab menyediakan } \\
\text { informasi yang tepat dan } \\
\text { akurat }\end{array}$ & 0,561 & 0,207 & Valid \\
\hline 3 & $\begin{array}{l}\text { Tidak membutuhkan waktu } \\
\text { yang lama untuk menyediakan } \\
\text { informasi }\end{array}$ & 0,810 & 0,207 & Valid \\
\hline 4 & $\begin{array}{l}\text { Aplikasi menyediakan } \\
\text { Informasi yang up to date }\end{array}$ & 0,838 & 0,207 & Valid \\
\hline
\end{tabular}

Tabel 5. Hasil Uji Validitas Variable Economic (Ekonomi) / (X3)

\begin{tabular}{|l|l|c|c|c|}
\hline No & \multicolumn{1}{|c|}{ Pemyataan } & $\begin{array}{c}\text { Total } \\
\text { Correlation } \\
\mathrm{R}_{\text {hitung }}\end{array}$ & $\begin{array}{c}\mathrm{R}_{\text {tabel }} \\
\mathrm{N}=91-2\end{array}$ & $\mathrm{Ket}$ \\
\hline 1. & $\begin{array}{l}\text { Aplikasi Grab menawarkan } \\
\text { biaya layanan jasa yang sesuai }\end{array}$ & 0,778 & 0,207 & Valid \\
\hline 2 & $\begin{array}{l}\text { Aplikasi Grab menawarkan } \\
\text { harga yang transfaran dengan } \\
\text { pengguna }\end{array}$ & 0,752 & 0,207 & Valid \\
\hline 3 & $\begin{array}{l}\text { Aplikasi Grab menawarkan } \\
\text { biaya yang konsisten }\end{array}$ & 0,742 & 0,207 & Valid
\end{tabular}

Tabel 6. Hasil Uji Validitas Variabel Control (Pengendalian dan Keamanan) / (X4)

\begin{tabular}{|c|c|c|c|c|}
\hline No & Pernyataan & $\begin{array}{c}\text { Total } \\
\text { Correlation } \\
\mathrm{R}_{\text {hitung }}\end{array}$ & $\begin{array}{c}\mathrm{R}_{\text {tabel }} \\
\mathrm{N}=91-2\end{array}$ & Ket \\
\hline 1. & $\begin{array}{l}\text { Aplikasi Grab menjamin } \\
\text { keamanan data pengguna }\end{array}$ & 0,799 & 0,207 & Valid \\
\hline 2 & $\begin{array}{lr}\text { Aplikasi Grab } & \text { memiliki } \\
\text { batasan-batasan } & \text { akses } \\
\text { pengguna } & \\
\end{array}$ & 0,772 & 0,207 & Valid \\
\hline 3 & $\begin{array}{l}\text { Aplikasi Grab aman dari } \\
\text { serangan virus }\end{array}$ & 0,808 & 0,207 & Valid \\
\hline 4 & $\begin{array}{l}\text { Aplikasi Grab memilki fitur } \\
\text { keamanan yang khusus (seperti } \\
\text { tombol darurat yang ada pada } \\
\text { aplikasi) }\end{array}$ & 0,752 & 0,207 & Valid \\
\hline
\end{tabular}

Tabel 7. Hasil Uji Validitas Variabel Efficiency (Efisiensi) / (X5)

\begin{tabular}{|c|c|c|c|c|}
\hline No & Pernyataan & $\begin{array}{c}\text { Total } \\
\text { Correlation } \\
\mathrm{R}_{\text {hitung }} \\
\end{array}$ & $\begin{array}{c}\mathrm{R}_{\text {tabel }} \\
\mathrm{N}=91-2\end{array}$ & Ket \\
\hline 1. & $\begin{array}{l}\text { Aplikasi Grab berhenti berfungsi, } \\
\text { Crash atau error }\end{array}$ & 0,708 & 0,207 & Valid \\
\hline 2 & $\begin{array}{l}\text { Aplikasi Grab mudah untuk } \\
\text { dioperasikan }\end{array}$ & 0,578 & 0,207 & Valid \\
\hline 3 & $\begin{array}{l}\text { Aplikasi Grab hemat waktu, } \\
\text { biaya dan tenaga }\end{array}$ & 0,725 & 0,207 & Valid \\
\hline 4 & $\begin{array}{l}\text { Tidak memerlukan sumber daya } \\
\text { manusia yang banyak untuk } \\
\text { menjalankan aplikasi dengan } \\
\text { berbagai kebutuhan informasi }\end{array}$ & 0,877 & 0,207 & Valid \\
\hline
\end{tabular}

Tabel 8. Hasil Uji Validitas Variabel Service (Pelayanan) / (X6)

\begin{tabular}{|c|c|c|c|c|}
\hline No & Pernyataan & $\begin{array}{l}\text { Total } \\
\text { Correlation } \\
R_{\text {hitung }}\end{array}$ & $\begin{array}{c}\mathrm{R}_{\text {tabel }} \\
\mathrm{N}=91-2\end{array}$ & Ket \\
\hline 1. & $\begin{array}{l}\text { Aplikasi Grab menawarkan } \\
\text { layanan pusat bantuan yang } \\
\text { akurat }\end{array}$ & 0,597 & 0,207 & Valid \\
\hline 2 & $\begin{array}{l}\text { Aplikasi Grab menyedikan fitur } \\
\text { bagikan lokasi perjalanan kepada } \\
\text { orang-orang terdekat yang dapat } \\
\text { dipantau secara real-time }\end{array}$ & 0,550 & 0,207 & Valid \\
\hline 3 & $\begin{array}{l}\text { Aplikasi Grab menyedikan fitur } \\
\text { pesan foto atau suara di Grab } \\
\text { Chat agar titik temu lebih akurat }\end{array}$ & 0,680 & 0,207 & Valid \\
\hline 4 & $\begin{array}{l}\text { Aplikasi Grab menyedikan fitur } \\
\text { tombol darurat (SOS) yang } \\
\text { efektif }\end{array}$ & 0,698 & 0,207 & Valid \\
\hline 5 & $\begin{array}{l}\text { Aplikasi Grab menyedikan fitur } \\
\text { lokasi penjemputan detail(POI) }\end{array}$ & 0,584 & 0,207 & Valid \\
\hline 6 & $\begin{array}{l}\text { Aplikasi Grab menyediakan fitur } \\
\text { mengubah tujuan dalam } \\
\text { perjalanan }\end{array}$ & 0,520 & 0,207 & Valid \\
\hline 7 & $\begin{array}{l}\text { Aplikasi Grab menyediakan fitur } \\
\text { membatalkan pemesanan efektif }\end{array}$ & 0,458 & 0,207 & Valid \\
\hline 8 & $\begin{array}{l}\text { Aplikasi Grab menyediakan } \\
\text { layanan rewards bagi pengguna } \\
\text { secara konsisten }\end{array}$ & 0,398 & 0,207 & Valid \\
\hline
\end{tabular}




\begin{tabular}{|l|l|l|l|l|}
\hline 8 & $\begin{array}{l}\text { Aplikasi Grab menyediakan } \\
\text { layanan rewards bagi pengguna } \\
\text { secara konsisten }\end{array}$ & 0,398 & 0,207 & Valid \\
\hline 9 & $\begin{array}{l}\text { Aplikasi Grab menyediakan } \\
\text { layanan kartu kamu yaitu untuk } \\
\text { metode pembayaran yang efektif }\end{array}$ & 0,538 & 0,207 & Valid \\
\hline 10 & $\begin{array}{l}\text { Aplikasi Grab menyediakan } \\
\text { layanan alamat tersimpan yang } \\
\text { efektif }\end{array}$ & 0,605 & 0,207 & Valid \\
\hline 11 & $\begin{array}{l}\text { Aplikasi Grab menyediakan fitur } \\
\text { mengemudi barang Grab untuk } \\
\text { tawaran menjadi driver yang } \\
\text { efektif }\end{array}$ & 0,657 & 0,207 & Valid \\
\hline 12 & $\begin{array}{l}\text { Aplikasi Grab menyediakan fitur } \\
\text { akun pengguna yang sesuai } \\
\text { dengan kebutuhan pengguna }\end{array}$ & 0,302 & 0,207 & Valid \\
\hline 13 & $\begin{array}{l}\text { Aplikasi Grab menyediakan fitur } \\
\text { layanan terjadwal untuk jadwal } \\
\text { perjalanan pengguna }\end{array}$ & 0,632 & 0,207 & Valid \\
\hline 14 & $\begin{array}{l}\text { Aplikasi Grab menyediakan } \\
\text { layanan pembayaran yang efektif }\end{array}$ & 0,613 & 0,207 & Valid \\
\hline 15 & $\begin{array}{l}\text { Aplikasi Grab menyediakan } \\
\text { layanan inbox untuk penawaran } \\
\text { khusus dari Grab }\end{array}$ & 0,657 & 0,207 & Valid \\
\hline 16 & $\begin{array}{l}\text { Aplikasi Grab menyediakan } \\
\text { layanan aktivitas bagi pengguna } \\
\text { yang telah melakukan pemesanan } \\
\text { denagan detail }\end{array}$ & 0,729 & 0,207 & Valid \\
\hline 17 & $\begin{array}{l}\text { Aplikasi Grab menawarkan } \\
\text { layanan jasa mobil, motor, } \\
\text { makanan, pengantaran, paket } \\
\text { hemat, pulsa/token, tickets, } \\
\text { tagihan, video dengan baik dan } \\
\text { sesuai bagi kebutuhan pengguna }\end{array}$ & 0,584 & 0,207 & Valid \\
\hline
\end{tabular}

Bedasarkan uji validitas pada tebel 3 hingga tabel 8 variabel Performance (X1), Information (X2), Economic (X3), control (X4), Efficiency (X5) dan Service (X6) seluruh item pernyataan valid karena nilai $r$ hitung $>r$ tabel $(0,207)$.

\subsection{Uji Reliabilitas}

Realibilitas diukur dengan menggunakan cronbach alpha. Variabel dikatakan reliable jika setiap pernyataan memberikan nilai cronbach alpha $>\mathrm{r}_{\text {tabel }}$ maka item pernyataan tersebut dikatakan reliable, Sedangkan apabila nilai Alpha Cronbach $<\mathrm{r}_{\text {tabel }}$ maka item pernyataan dinyatakan tidak reliabel. Nilai r Product Moment diperoleh dengan menggunakan taraf signifikan 5\% (91-2) $=89$. Karena nilai 89 tidak ada pada $r_{\text {tabel }} 89$ maka diambil nilai yang terdekat yaitu nilai yang diperoleh $r_{\text {tabel }}=0,207$. Berikut hasil uji reliabilitas dapat dilihat pada tabel dibawah ini.
Tabel 9. Hasil

$\mathrm{Uji}$

Reliabilitas

Performance (Kinerja) / (X1)

Reliability Statistics

\begin{tabular}{|c|c|}
\hline $\begin{array}{c}\text { Cronbach's } \\
\text { Alpha }\end{array}$ & N of Items \\
\hline, 622 & 4 \\
\hline
\end{tabular}

Tabel 10. Hasil Uji Reliabilitas Information (Informasi) / (X2)

Reliability Statistics

\begin{tabular}{|c|c|}
\hline $\begin{array}{c}\text { Cronbach's } \\
\text { Alpha }\end{array}$ & N of Items \\
\hline, 650 & 4 \\
\hline
\end{tabular}

Tabel 11. Hasil Uji Reliabilitas Economic (Ekonomi) / (X3)

\section{Reliability Statistics}

\begin{tabular}{|c|c|}
\hline $\begin{array}{c}\text { Cronbach's } \\
\text { Alpha }\end{array}$ & N of Items \\
\hline, 615 & 3 \\
\hline
\end{tabular}

Tabel 12. Hasil Uji Reliabilitas Control (Pengendalian dan Keamanan) / (X4)

Reliability Statistics

\begin{tabular}{|c|c|}
\hline $\begin{array}{c}\text { Cronbach's } \\
\text { Alpha }\end{array}$ & N of Items \\
\hline, 783 & 4 \\
\hline
\end{tabular}

Tabel 13. Hasil Uji Reliabilitas Efficiency (Efisiensi) / (X5)

\section{Reliability Statistics}

\begin{tabular}{|c|c|}
\hline $\begin{array}{c}\text { Cronbach's } \\
\text { Alpha }\end{array}$ & N of Items \\
\hline, 696 & 4 \\
\hline
\end{tabular}


Tabel 14. Hasil Uji Reliabilitas Service (Pelayanan) / (X6)

Reliability Statistics

\begin{tabular}{|c|c|}
\hline $\begin{array}{c}\text { Cronbach's } \\
\text { Alpha }\end{array}$ & N of Items \\
\hline, 874 & 17 \\
\hline
\end{tabular}

Hasil uji reliabilitas semua variabel setiap item pernyataan nilai cronbach's alpha > 0,207, maka dapat disimpulkan bahwa kuesioner tersebut reliabel (handal).

\subsection{Hasil Uji Regresi Linier Berganda}

Regresi berganda merupakan pengembangan dari regresi linier sederhana, yaitu sama sama alat yang dapat digunakan untuk memprediksi permintaan di masa akan datang berdasarkan data masa lalu atau untuk mengetahui pengaruh satu atau lebih variabel bebas (independent) terhadap satu variabel tak bebas (dependent)[18]. Peneliti memperoleh hasil uji regresi berganda seperti yang ditunjukan pada tabel 15 dibawah ini.

Tabel 15. Hasil Regresi Berganda.

\begin{tabular}{|c|l|c|c|}
\hline \multirow{2}{*}{\multicolumn{2}{|c|}{}} & \multicolumn{2}{c|}{$\begin{array}{c}\text { Unstandardized } \\
\text { Coefficients }\end{array}$} \\
\cline { 3 - 4 } \multicolumn{2}{c|}{ Model } & B & $\begin{array}{c}\text { Std. } \\
\text { Error }\end{array}$ \\
\hline \multirow{2}{*}{1} & Constant) & 4,143 & 2,364 \\
\cline { 2 - 4 } & Performance &, 975 &, 245 \\
\cline { 2 - 4 } & Information &, 506 &, 159 \\
\cline { 2 - 4 } & Economic &,- 343 &, 480 \\
\cline { 2 - 4 } & Control & 2,173 &, 407 \\
\hline & Efficiensy & 2,121 &, 186 \\
\cline { 2 - 4 } & Service &, 687 &, 143 \\
\hline
\end{tabular}

Dari tabel 15 diatas, maka diperoleh nilai $b_{1}=0,975, b_{2}=0,506, b_{3}=-, 343, b_{4}=$ $2,173, b_{5}=2,121, b_{6}=0,687$ dan nilai (Constant) $\mathrm{a}=4,143$ kemudian nilai $\mathrm{a}$ dan $\mathrm{b}$ disusun ke dalam persamaan regresi linear berganda $Y=a+b_{1} X_{1}+b_{2} X_{2}+b_{3} X_{3},+$ $\mathrm{b}_{4} \mathrm{X}_{4}+\mathrm{b}_{5} \mathrm{X}_{5}+\mathrm{b}_{6} \mathrm{X}_{6}$ maka persamaan regresinya adalah $\mathrm{Y}=4,143+0,975+0,506$ $+-, 343+2,173+2,121+0,687$

\section{$1 \quad$ Uji T}

Untuk mengetahui pengaruh dari setiap variabel independen terhadap variabel Performance (X1), Information (X2), Economic (X3), Control (X4), Efficiency (X5) dan Service (X6) terhadap variabel dependen variabel dependen. $\mathrm{T}_{\text {hitung }}$ diperoleh dengan menggunakan $\alpha=0,05$ (dua sisi) dengan $\mathrm{dk}=\mathrm{n}-\mathrm{k}-1(91-6-1)=84$. Berdasarkan nilai $\alpha=0,05$ dan $\mathrm{dk}=84$ diperoleh $\mathrm{T}_{\text {tabel }}=2,000$ seperti yang ditunjukkan pada tabel 16 dibawah ini.

Tabel 16. Hasil Uji T

\begin{tabular}{|c|c|c|c|c|c|}
\hline \multirow[b]{2}{*}{ Model } & \multicolumn{2}{|c|}{$\begin{array}{l}\text { Unstandardized } \\
\text { Coefficients }\end{array}$} & \multirow{2}{*}{$\begin{array}{c}\begin{array}{c}\text { Standardized } \\
\text { Coefficients }\end{array} \\
\text { Beta }\end{array}$} & \multirow[b]{2}{*}{$\mathrm{t}$} & \multirow[b]{2}{*}{ Sig. } \\
\hline & $\mathrm{B}$ & Std. Error & & & \\
\hline 1 (Constant) & 4,143 & 2,364 & & 1,753 &, 083 \\
\hline Performance & ,975 &, 245 & , 135 & 3,979 &, 000 \\
\hline Information &, 506 & 159 &, 074 & 3,188 &, 002 \\
\hline Economic &,- 343 & , 480 &,- 036 &,- 715 &, 477 \\
\hline Control & 2,173 & ,407 &, 326 & 5,339 &, 000 \\
\hline Efficiensy & 2,121 & 186 &, 335 & 11,384 &, 000 \\
\hline Service & 687 &, 143 &, 330 & 4,797 &, 000 \\
\hline
\end{tabular}

a. Hasil uji T pada variabel Performance dapat dilihat bahwa nilai Sig yaitu $0,000<0,05$ dan nilai $T_{\text {hitung }} 3,979>$ $\mathrm{T}_{\text {tabel }}$ 2,000 maka dapat artikan secara parsial (terpisah) bahwa variabel Performance (X1) berpengaruh terhadap kepuasan pengguna aplikasi Grab (Y).

b. Hasil uji $\mathrm{T}$ pada variabel Information menunjukkan Sig 0,002 < 0,05 dan nilai $\mathrm{T}_{\text {hitung }} 3,188>\mathrm{T}_{\text {tabel }} 2,000$ maka dapat diartikan secara persial (terpisah) bahwa variabel Information (X2) berpengaruh terhadap kepuasan pengguna aplikasi Grab (Y).

c. Hasil uji $\mathrm{T}$ pada variabel Economic menunjukkan nilai Sig 0,477>0,05 dan nilai $\mathrm{T}_{\text {hitung }}-715<\mathrm{T}_{\text {tabel }} 2,000$ maka dapat diartikan secara persial (terpisah) bahwa variabel economic 
(X3) tidak berpengaruh terhadap kepuasan pengguna aplikasi Grab (Y).

d. Hasil uji $\mathrm{T}$ pada variabel Control menunjukkan Sig 0,000 $<0,05$ dan

e. variabel Efficiency (X4) berpengaruh terhadap kepuasan pengguna aplikasi Grab (Y).

f. Hasil uji t pada variabel Service menunjukkan Sig 0, nilai $\mathrm{T}_{\text {hitung }} 5,339$ $>\mathrm{T}_{\text {tabel }} 2,000$ maka dapat diartikan secara persial (terpisah) bahwa variabel Control (X4) berpengaruh terhadap kepuasan pengguna aplikasi Grab (Y).

g. Hasil uji $\mathrm{T}$ pada variabel Efficiency menunjukkan Sig 0,000 $<0,05$ dan nilai $\mathrm{T}_{\text {hitung }} 11,384>\mathrm{T}_{\text {tabel }} 2,000$ maka dapat diartikan secara persial (terpisah) bahwa $000<0,05$ dan nilai $\mathrm{T}_{\text {hitung }}$ $4,797>\mathrm{T}_{\text {tabel }} 2,000$ maka dapat diartikan secara persial (terpisah) bahwa variabel Service (X5) berpengaruh terhadap kepuasan pengguna aplikasi Grab (Y).

\section{$2 \quad$ Uji F}

Untuk mengetahui pengaruh dari setiap variabel independen terhadap variabel dependen variabel dependen. Nilai signifikan $<0.05$ dan nilai $\mathrm{F}_{\text {hitung }}>\mathrm{F}_{\text {tabel }}$ maka artinya variabel bebas secara besama atau simultan memiliki pengaruh terhadap variabel kepuasan pennguna (Y). Cara menentukan $\mathrm{F}_{\text {tabel }} \mathrm{dk}_{1}=\mathrm{k}-1$ atau 6-1=5, dan $\mathrm{dk}_{2}=\mathrm{n}-\mathrm{k}$ atau 91-6 =85 ( $\mathrm{n}=$ jumlah responden; $\mathrm{k}=\mathrm{jumlah}$ variabel independen), jadi nilai $F$ tabel adalah 2,33. Nilai Uji $F$ dapat dijelaskan melalui tabel 17 dibawah ini.
Tabel 17. Hasil Uji F

\begin{tabular}{|c|c|c|c|c|c|}
\hline \multicolumn{6}{|c|}{ ANOVA $^{\mathrm{a}}$} \\
\hline Model & Sum of Squares & $\mathrm{df}$ & Mean Square & $\mathrm{F}$ & Sig. \\
\hline \begin{tabular}{|ll}
1 & Regression
\end{tabular} & 29624,987 & 6 & 4937,498 & 581,722 &, $000^{b}$ \\
\hline Residual & 712,969 & 84 & 8,488 & & \\
\hline Total & 30337,956 & 90 & & & \\
\hline
\end{tabular}

a. Dependent Variable: Kepuasan Pengguna

b. Predictors: (Constant), Service, Information, Efficiensy, Performance, Economic, Control

Berdasarkan tabel uji F menunjukkan hasil nilai signifikasi untuk pengaruh variabel Performance (X1), Information (X2), Economy (X3), Control (X4), Efficiency (X5) dan Service (X6) secara simultan terhadap Y adalah sebesar 0,000 < 0,05 dan nilai $F_{\text {hitung }} 581,722>F_{\text {tabel }} 2,33$ sehingga secara keseluruhan/bersama dinyatakan bahwa variabel performance (X1) information (X2), ecconomy (X3), control (X4), efficiency (X5) dan service (X6) secara simultan (berama-sama) berpengaruh terhadap kepuasan pengguna (Y).

\section{Uji Determinasi}

Selanjutnya dalam penelitian ini, peneliti juga melakukan atau mencari nilai uji koefisien determinasi, dimana nilai hasil uji determinasi tersebut dapat dilihat melalui tabel 18 dibawah ini.

Tabel 18. Hasil Uji Koefisien Determinasi

\begin{tabular}{|c|c|c|c|c|c|}
\hline \multicolumn{6}{|c|}{ Model Summary ${ }^{b}$} \\
\hline Model & $\mathrm{R}$ & R Square & $\begin{array}{c}\text { Adjusted R } \\
\text { Square }\end{array}$ & $\begin{array}{l}\text { Std. Error of } \\
\text { the Estimate }\end{array}$ & $\begin{array}{l}\text { Durbin- } \\
\text { Watson }\end{array}$ \\
\hline 1 & ,988a & ,976 & ,975 & 2,913 & 1,857 \\
\hline
\end{tabular}

a. Predictors: (Constant), Service, Information, Efficiensy, Performance, Economic, Control

b. Dependent Variable: Kepuasan Pengguna

Berdasarkan hasil uji determinasi diketahui nilai koefisien korelasi $\left(\mathrm{R}=, 988^{\mathrm{a}}\right)$, hal ini mengandung arti bahwa variabel bebas yang diamati mempunyai hubungan yang kuat dengan variabel terikat (dependent). Sedangkan koefisien determinasi ( $R$ Square) sebesar 0,976 mengandung arti bahwa pengaruh variabel 
Performance (X1) Information (X2), Economy (X3), Control (X4), Efficiency (X5) dan Service (X6) secara bersamasama/ (simultan) terhadap kepuasan pengguna Grab Lubuklinggau adalah sebesar 97,6 Sedangkan 2,4\% dipengaruhi oleh variabel bebas lain yang tidak diteliti.

\section{KESIMPULAN}

Berdasarkan hasil analisis aplikasi

Grab Lubuklinggau terhadap kepuasan pengguna menggunakan Framework PIECES maka dapat disimpulkan:

a. Berdasarkan dari uji validitas setiap butir pernyataan yang dilakukan kepada 91 responden pada variabel Performance, Information, Economic, Control, Efficiency, dan Service dinyatakan valid dengan nilai $R_{\text {hitung }}>$ $\mathrm{R}_{\text {tabel }}$ 0,207. Dan untuk hasil uji reliabilitas variabel Performance, Information, Economic, Control, Efficiency, dan Service dengan nilai Cronbach's Alpha > $\mathrm{r}_{\text {tabel }}$ 0,207 maka dapat disimpulkan bahwa kuesioner tersebut reliabel (handal).

b. Hasil Uji T parsial (terpisah) variabel Performance, Information, Control, Efficiency, dan Service berpengaruh signifikan terhadap kepuasan pengguna (konsumen) Grab Lubuklinggau, sedangkan diketahui nilai Sig variabel Economic sebesar 0,477>0,05 dan $\mathrm{T}_{\text {hitung }}-715<\mathrm{T}_{\text {tabel }} 2,000$ sehingga variabel Economic tidak berpengaruh signifikan terhadap kepuasan pengguna Grab Lubuklinggau.

c. Hasil uji F menunjukkan nilai signifikan variabel Performance, Information, Economic, Control, Efficiency, dan Service secara simultan (bersama-sama) terhadap kepuasan pengguna aplikasi Grab Lubuklinggau adalah sebesar 0,000 $<0,05$ dan nilai $F_{\text {hitung }} 581,722>\mathrm{F}_{\text {tabel }}$ 2,33 sehingga dapat disimpulkan bahwa variabel Performance, Information,
Economic, Control, Efficiency, dan Service secara simultan berpengaruh terhadap kepuasan pengguna aplikasi Grab Lubuklinggau.

d. Hasil hitung koefisien determinasi diketahui nilai R Square sebesar 0,976 artinya secara bersama-sama kualitas aplikasi Grab variabel bebas berupa variabel Performance, Information, Economic, Control, Efficiency, dan Service terhadap kepuasan pengguna aplikasi Grab Lubuklinggau sebesar 97,6\% sementara $2,4 \%$ dipengaruhi oleh variabel-variabel lainnya yang tidak diteliti dalam penelitian ini.

\section{SARAN}

Sehubungan dengan hasil penelitian yang telah disimpulkan, peneliti merumuskan beberapa saran pada perusahaan Grab Lubuklinggu sebagai berikut :

a. Hendaknya pihak Grab Lubuklinggau untuk menawarkan biaya layanan jasa yang lebih sesuai, harga yang lebih transparan, menawarkan biaya yang lebih konsisten, karena dari hasil kuesioner yang telah diberikan, diketahui bahwa pengguna kurang puas terhadap biaya layanan jasa / layanan Economic yang ditawarkan pada aplikasi Grab Lubuklinggau.

b. Bagi peneliti selanjutnya agar dalam pengumpulan data sebaiknya melihat dari sudut pandang pihak lain, tidak hanya menurut persepsi konsumen Grab Lubuklinggau saja, namun bisa ditambahkan juga menurut persepsi driver Grab agar didapat perbandingan hasil.

c. Dari hasil penelitian kepuasan pengguna terhadap aplikasi Grab Lubuklinggau ada $2,4 \%$ variabel-variabel lain yang belum diteliti dan hal tersebut juga mempengaruhi kepuasan pengguna 
(konsumen) Grab Lubuklinggau, jadi peneliti menyarankan agar kemudian hari akan ada penelitian menggunakan variabel ataupun metode lain yang belum pernah diteliti agar didapat hasil yang lebih baik lagi.

\section{DAFTAR PUSTAKA}

[1] C. Wulandari, L. Y. Syah, and L. A. Abdillah, "Analisa Tingkat Kepuasan Layanan TI ( Studi Kasus Pada Aplikasi Gojek )," Anal. Tingkat Kepuasan Layanan TI ( Stud. Kasus Pada Apl. Gojek), vol. 8, no. 8, pp. 7-12, 2016.

[2] A. Supriyatna, "Analisis Dan Evaluasi Kepuasan Pengguna Sistem Informasi Perpustakaan Dengan Menggunakan Pieces Framework," J. Pilar, vol. 11, no. 1, pp. 41-50, 2015.

[3] M. . Safarudin, "Analisis Kepuasan Pengguna Marketplace Tokopedia Dengan Metode PIECES di Tokopedia Community Batam," SNISTEK, no. 1, pp. 109-114, 2018.

[4] Yodi, "Analisis Sistem Informasi Akademik Mahasiswa Pada Stmik Gici Batam Menggunakan Metode Pieces," Sist. Inf., vol. 5, no. 2, pp. 1-9, 2017.

[5] L. Hakim and Sari, "Analisis Tingkat Kepuasan Pelanggan Terhadap Pelayanan Pt. Tiki Lubuklinggau Menggunakan Metode Servqual," vol. 3, no. 2, 2018.

[6] A. . Ivan, "Desain target optimal," Jakarta, 2015.

[7] Y. Sutanto, "Analisis kepuasan pengguna website manajemen informatika dengan metode eucs berbasis cms," vol. 2 , no. 1 , pp. 1$18,2015$.

[8] M. Suyatno, Pengantar Teknologi Informasi Untuk Bisnis. Yogyakarta: Andi, 2015.

[9] I. Darimi, "Teknologi Informasi Dan Komunikasi Sebagai Media Pembelajaran Pendidikan Agama
Islam Efektif," Pendidik. Teknol. Inf, vol. 1, no. 2, pp. 111-121, 2017.

[10] M. . Irawan, R. Saeduddin, and R. Fauzi, "Penerapan Manajemen Layanan Teknologi Informasi Pada Perusahaan Manufaktur Menggunakan Itil Versi 3 Domain Service Strategy Studi Kasus: Pt Albasia Nusa Karya," vol. 5, no. 3, pp. 7229-7235, 2018.

[11] J. Hafasri, M. . Irfani, and F. Nopriani, "Analisis Sistem Informasi Analisis Pengukuran Kualitas Penggunaan Sistem Informasi Akademik (Studi Kasus Sistem Informasi Akademik STIQ Al-Lathifiyyah Palembang), JUSIFO, vol. 5, no. 2, pp. 81-90, 2019.

[12] H. Utomo, E. M. . Jonemaro, and M. . Ananta, "Perbandingan Usabilitas Aplikasi Taxi Online Android (Grab-car dan Uber) Menggunakan Unified Theory of Acceptance and Use of Technology (UTAUT)," Pengemb. Teknol. Inf. dan Ilmu Komput, vol. 1, no. 12, pp. $1708-$ 1717, 2017.

[13] R. . Kristy and W. . Kusuma, "Analisis Tingkat Kepuasan Dan Tingkat Kepentingan Penerapan Sistem Informasi Universitas Muhammadiyah Malang," Eng. Sains J, vol. 2, no. 1, pp. 17-24, 2018.

[14] L. Hakim and T. Pertiwi, "Analisis Tingkat Kepuasan Pengguna Terhadap Website Stkip Pgri Lubuklinggau Menggunakan Metode Pieces," J. Teknol. Inf. dan Komput. Politek. Sekayu, vol. 9, no. 2, pp. 26-36, 2018.

[15] Sugiyono, Metode Penelitian Pendidikan. Bandung: Alfabeta, 2018.

[16] H. O. L. Wijaya, "Implementasi Metode Pieces Pada Analisis Website Kantor Penanaman Modal Kota Lubuklinggau," JUSIM, vol. 3, no. 1, pp. 46-55, 2018.

[17] A. Supriyatna and V. Maria, “. 
Supriyatna and V. Maria, "Pengukuran Tingkat Kepuasan

Pengguna Sistem Informasi Djp Online Pelaporan Spt Pajak," vol. 4, pp. 147-154, 2017.

[18] M. . Pranita, D. . Zulfikar, and C. . Gunawan, "Analisis Kepuasan Pengguna Sistem Keagenan PERISAI Menggunakan End User Computing Satisfaction (Studi Kasus: BPJS Ketenagakerjaan Kantor Cabang Palembang)," JUSIFO, vol. 5, no. 2, pp. 91-104, 2019. 